Abstracta Iranica Abstracta Iranica

Revue bibliographique pour le domaine irano-aryen

Volume 40-41 | 2019

Comptes rendus des publications de 2017-2018

\title{
Sajad Amiri Bavandpour, "A Survey of Christian Arab Sources for the Study of Sasanian History"
}

\section{Christelle Jullien}

\section{(2) OpenEdition \\ 12 Journals}

\section{Édition électronique}

URL : http://journals.openedition.org/abstractairanica/50746

DOI : 10.4000/abstractairanica.50746

ISBN : 1961-960X

ISSN : 1961-960X

Éditeur :

CNRS (UMR 7528 Mondes iraniens et indiens), Éditions de l'IFRI

Référence électronique

Christelle Jullien, «Sajad Amiri Bavandpour, "A Survey of Christian Arab Sources for the Study of Sasanian History" », Abstracta Iranica [En ligne], Volume 40-41 | 2019, document 1, mis en ligne le 30 décembre 2019, consulté le 17 avril 2021. URL : http://journals.openedition.org/abstractairanica/ 50746 ; DOI : https://doi.org/10.4000/abstractairanica.50746

Ce document a été généré automatiquement le 17 avril 2021.

Tous droits réservés 


\title{
Sajad Amiri Bavandpour, "A Survey of Christian Arab Sources for the Study of Sasanian History"
}

\author{
Christelle Jullien
}

\section{RÉFÉRENCE}

Sajad Amiri Bavandpour. "A Survey of Christian Arab Sources for the Study of Sasanian History”, e-Sasanika 19, 2017, 14p.

1 Cet article en persan est une présentation historiographique des principales études concernant sources arabes chrétiennes relatives à l'histoire sassanide. L'auteur y recense chacun des textes produits par les communautés chrétiennes jusqu'au XIII ${ }^{\mathrm{e}}$ siècle. On peut signaler à présent l'étude de G. Gianazza, Șalïbā ibn Yūhannā al-Mawșilī. I libri dei misteri (Kitāb asfār al-asrār) (Patrimonio culturale arabo cristiano 12), Rome, 2016, avec l'édition critique du texte arabe en cours dans la collection Patrimoine Arabe Chrétien du CEDRAC de Beyrouth.

\section{AUTEURS}

\section{CHRISTELLE JULLIEN}

CNRS, Mondes iranien et indien, Paris 